\title{
Vegetation responses to season of fire in an aseasonal, fire- prone fynbos shrubland
}

\author{
Tineke Kraaij ${ }^{\text {Corresp.. }}{ }^{1}$ ， Richard M Cowling ${ }^{2}$, Brian W van Wilgen ${ }^{3}$, Diba R Rikhotso ${ }^{4}$, Mark Difford ${ }^{2}$ \\ ${ }^{1}$ School of Natural Resource Management, Nelson Mandela Metropolitan University, George, South Africa \\ 2 Botany Department, Nelson Mandela Metropolitan University, Port Elizabeth, South Africa \\ 3 Centre for Invasion Biology, Department of Botany and Zoology, University of Stellenbosch, Stellenbosch, South Africa \\ 4 Garden Route Scientific Services, South African National Parks, Knysna, South Africa \\ Corresponding Author: Tineke Kraaij \\ Email address: tineke.kraaij@nmmu.ac.za
}

Season of fire has marked effects on floristic composition in fire-prone Mediterraneanclimate shrublands. In these winter-rainfall systems, summer-autumn fires lead to optimal recruitment of overstorey proteoid shrubs (non-sprouting, slow-maturing, serotinous Proteaceae) which are important to the conservation of floral diversity. We explored whether fire season has similar effects on early establishment of five proteoid species in the eastern coastal part of the Cape Floral Kingdom (South Africa) where rainfall occurs year-round and where weather conducive to fire and the actual incidence of fire are largely aseasonal. We surveyed recruitment success (ratio of post-fire recruits to pre-fire parents) of proteoids after fires in different seasons. We also planted proteoid seeds into exclosures, designed to prevent predation by small mammals and birds, in cleared (intended to simulate fire) fynbos shrublands at different sites in each of four seasons and monitored their germination and survival to one year post-planting (hereafter termed 'recruitment'). Factors (in decreasing order of importance) affecting recruitment success in the post-fire surveys were species, pre-fire parent density, post-fire age of the vegetation at the time of assessment, and fire season, whereas rainfall (for six months post-fire) and fire return interval (>7 years) had little effect. In the seed-planting experiment, germination occurred during the cooler months and mostly within two months of planting, except for summer-plantings, which took 2-3 months longer to germinate. Although recruitment success differed significantly among planting seasons, sites and species, significant interactions occurred among the experimental factors. In both the post-fire surveys and seed planting experiment, recruitment success in relation to fire- or planting season varied greatly within and among species and sites. Results of these two datasets were furthermore inconsistent, suggesting that proteoid recruitment responses are not related to the season of fire. Germination appeared less rainfall-dependent than in winterrainfall shrublands, suggesting that summer drought-avoiding dormancy is limited and has 
less influence on variation in recruitment success among fire seasons. The varied response of proteoid recruitment to fire season (or its simulation) implies that burning does not have to be restricted to particular seasons in eastern coastal fynbos, affording more flexibility for fire management than in shrublands associated with winter rainfall. 
3

4

5

6

7

8

9

10

11

12

13

14

15

16

17

18

19

20

\section{Vegetation Responses to Season of Fire in an Aseasonal, Fire-Prone Fynbos Shrubland}

[Short title: Eastern Fynbos Responses to Fire Season]

\section{Tineke Kraaij $^{1 *}$, Richard M. Cowling ${ }^{2}$, Brian W. van Wilgen ${ }^{3}$, Diba R. Rikhotso ${ }^{4}$ and Mark Difford ${ }^{2}$}

${ }^{1}$ School of Natural Resource Management, Nelson Mandela Metropolitan University, George, South Africa

${ }^{2}$ Botany Department, Nelson Mandela Metropolitan University, Port Elizabeth, South Africa

${ }^{3}$ Centre for Invasion Biology, Department of Botany and Zoology, Stellenbosch University, Stellenbosch, South Africa

${ }^{4}$ Garden Route Scientific Services, South African National Parks, Knysna, South Africa

* Corresponding author e-mail: tineke.kraaij@nmmu.ac.za 


\section{Abstract}

22 Season of fire has marked effects on floristic composition in fire-prone Mediterranean-climate 23 shrublands. In these winter-rainfall systems, summer-autumn fires lead to optimal recruitment of important to the conservation of floral diversity. We explored whether fire season has similar effects on early establishment of five proteoid species in the eastern coastal part of the Cape Floral Kingdom (South Africa) where rainfall occurs year-round and where weather conducive to fire and the actual incidence of fire are largely aseasonal. We surveyed recruitment success (ratio of post-fire recruits to pre-fire parents) of proteoids after fires in different seasons. We also planted proteoid seeds into exclosures, designed to prevent predation by small mammals and birds, in cleared (intended to simulate fire) fynbos shrublands at different sites in each of four seasons and monitored their germination and survival to one year post-planting (hereafter termed 'recruitment'). Factors (in decreasing order of importance) affecting recruitment success in the post-fire surveys were species, pre-fire parent density, post-fire age of the vegetation at the time of assessment, and fire season, whereas rainfall (for six months post-fire) and fire return interval ( $>7$ years) had little effect. In the seed-planting experiment, germination occurred during the cooler months and mostly within two months of planting, except for summer-plantings, which took 2-3 months longer to germinate. Although recruitment success differed significantly among planting seasons, sites and species, significant interactions occurred among the experimental factors. In both the post-fire surveys and seed planting experiment, recruitment success in relation to fire- or planting season varied greatly within and among species and sites. Results of these two datasets were furthermore inconsistent, suggesting that proteoid recruitment responses are not related to the season of fire. Germination appeared less rainfall-dependent than in winterrainfall shrublands, suggesting that summer drought-avoiding dormancy is limited and has less influence on variation in recruitment success among fire seasons. The varied response of proteoid recruitment to fire season (or its simulation) implies that burning does not have to be restricted to particular seasons in eastern coastal fynbos, affording more flexibility for fire management than in shrublands associated with winter rainfall.

\section{Introduction}

Fires ignited by lightning are the dominant natural disturbance in the species- and endemic-rich fynbos shrublands (Myers et al. 2000) of the Cape Floral Kingdom (CFK), South Africa (Kruger \& Bigalke 1984; Seydack et al. 2007). Empirical evidence indicates that season of fire can affect species abundance and floristic composition in fire-prone Mediterranean-climate shrublands of the world (Bond 1984; Enright \& Lamont 1989; Midgley 1989; Domínguez et al. 2002; Keeley 2006; Moreno et al. 2011; Céspedes et al. 2012). Knowing how species respond to fire regimes (including fire season) is essential for ecologically sustainable management (Driscoll et al. 2010).

In the CFK, existing fynbos fire management protocols restrict burning to the late summer-early autumn period (van Wilgen 2009). These protocols are largely based on knowledge of the summer-autumn fire regimes in the west (Kruger \& Bigalke 1984; van Wilgen et al. 1994) where the climate is Mediterranean, with cool, wet winters and warm, dry summers (van Wilgen 1984), and where post-fire plant recruitment is accordingly seasonally constrained (van Wilgen \& Viviers 1985; Midgley 1989). In contrast, rainfall in the eastern coastal part of the CFK occurs year-round (Schulze 1965), weather conditions conducive to fires (Kraaij et al. 
66

67

68

69

70

71

72

73

74

75

76

77

78

79

80

81

82

83

84

85

86

87

88

89

90

91

92

93

94

95

96

97

98

99

100

101

102

103

104

105

106

107

108

109

110

111

2013a) and fire occurrence (Kraaij et al. 2013b) are largely aseasonal, and comparatively little is known about the effects of fire season on post-fire plant recovery (van Wilgen 2009).

Obligate reseeding shrubs are often particularly susceptible to population declines under fire regimes that do not provide favourable post-fire recruitment conditions. This is evident in shrubs regenerating from soil-stored seed banks in Californian chaparral (Keeley 2006) and Mediterranean Basin maquis (Moreno et al. 2011; Céspedes et al. 2012), and from canopy-stored (serotinous) seed banks (almost exclusively members of the Proteaceae; hereafter 'proteoids') in Australian kwongan (Bell 2001; Lamont et al. 1991a; Enright et al. 1998) and South African fynbos (Jordaan 1949; Bond et al. 1984). Proteoids release their whole seed bank post-fire (Lamont et al. 1991b) and the seeds are short-lived after release, mostly germinating during the first favourable period (Cowling \& Lamont 1987). Germination and early survival are critical phases in post-fire proteoid establishment (Bond 1984; Midgley 1988; Midgley et al. 1989; Mustart et al. 2012) while subsequent mortality of saplings is low (2-7\% over a period of 4-6 years, Kraaij et al. 2013c). Inter-fire recruitment is rare and seedlings often die (Gill 1975; Keeley et al. 2011). Extreme variation in post-fire recruitment is characteristic of proteoids (van Wilgen \& Viviers 1985; Cowling \& Gxaba 1990), but in the Mediterranean-climate shrublands of the CFK and Australia, proteoid recruitment is generally higher after fires in summer-autumn than in winter-spring (van Wilgen \& Viviers 1985; Cowling \& Lamont 1987; Bradstock \& O’Connell 1988; Enright \& Lamont 1989; Midgley 1989).

Variation in recruitment success has been explained on the basis of: the size of pre-fire seed banks which vary with plant age (Le Maitre 1990; Lamont et al. 1991a; Kraaij et al. 2013c; Treurnicht et al. 2016), plant phenology (Jordaan 1949), pre-fire plant density (Bond et al. 1984; Le Maitre 1988; Cowling \& Gxaba 1990), pre-dispersal seed predation (Esler \& Cowling 1990), post-dispersal seed predation and decay (and thus duration of seed exposure between release and germination; Bond 1984), the role of fire in breaking seed dormancy (Bond et al. 1990, 1999; Brown \& Botha 2004), climatic conditions favourable to germination, and the extent of postgermination mortality due to fungal pathogens, vertebrate and invertebrate herbivory, droughtstress and density-dependent thinning (Cowling \& Lamont 1987; Enright \& Lamont 1989; Midgley 1989; Botha \& Le Maitre 1992; Mustart et al. 2012). Mechanisms accounting for effects of fire season, in particular, on recruitment success of obligate reseeding shrubs in Mediterranean-climate shrublands include (i) plant phenology (timing of seed production/dormancy/dispersal/predation in relation to timing of fire), (ii) interactions between fire season and fire intensity affecting the provisioning of germination cues, and (iii) the timing of climatic conditions favourable to germination (temperature stratification) and seedling survival (post-fire rainfall/desiccation) (Bond et al. 1990; Enright \& Lamont 1989; Moreno et al. 2011; Céspedes et al. 2012; Mustart et al. 2012).

Few studies have examined the effects of fire season on plant populations in fire-prone shrublands with a non-seasonal rainfall regime, where both fire season and intensity are variable (Bradstock et al. 2002; van Wilgen 2009). In eastern inland fynbos, Heelemann et al. (2008) established that plant phenology and thus, seed availability, do not impose seasonal constraints on proteoid recruitment (cf. Le Maitre 1988), but that recruitment peaked after fires in autumn and spring, presumably coinciding with the bimodal peaks in rainfall. We aimed to determine whether post-fire recruitment seasonality in the eastern coastal (climatically more equable) part of the CFK differs from that in other parts of the CFK or whether recruitment success is unrelated to fire season. In addition to field surveys of recruitment success after fires in different seasons, our approach entailed a seed planting experiment aimed at identifying the mechanisms 
112 that determine post-fire recruitment seasonality. Finally, we explored the management

113 implications of our findings to inform ecological fire management protocols in fynbos

114 shrublands associated with a non-seasonal rainfall regime.

116 Materials \& Methods

\section{Study area}

118 We focussed on the eastern coastal CFK, and in particular, the coastal (south-facing and thus cooler and wetter) slopes of the Outeniqua Mountains (east of the Touw River) and Tsitsikamma Mountains $\left(33.80^{\circ} \mathrm{S}, 22.59^{\circ} \mathrm{E}-34.01^{\circ} \mathrm{S}, 24.26^{\circ} \mathrm{E}\right.$; Figure 1). A large portion of the area occurs within the Garden Route National Park (Kraaij et al. 2011).

Owing to maritime influence, the climate of the area is relatively equable (Schulze 1965). Mean minimum and maximum temperatures range from $7^{\circ} \mathrm{C}$ and $19^{\circ} \mathrm{C}$ in June to $15^{\circ} \mathrm{C}$ and $26^{\circ} \mathrm{C}$ in January (Bond 1981; Southwood 1984). Rainfall occurs throughout the year, with 19\% of annual rain falling during summer, $23 \%$ during autumn, $28 \%$ during winter, and $30 \%$ during spring (over the period 1993-2013 at the town of Plettenberg Bay, centrally positioned within the study area; Figure 1). Mean annual rainfall increases eastwards, from 820 to $1078 \mathrm{~mm}$ in the Outeniqua and Tsitsikamma Mountains, respectively (Bond 1981; Southwood 1984). The proportion falling as summer rain also increases eastwards (Schulze 1965). While in the westernCFK, weather conditions suitable for fires dominate in the dry summer months (van Wilgen 1984), they are less seasonal in the eastern coastal CFK (Kraaij et al. 2013a) with fires occurring any time of year (Kraaij et al. 2013b). Hot and dry katabatic berg winds in autumn and winter are associated with increased incidence, size and severity of fires (Kraaij et al. 2013a) and their spread from the northern to the southern slopes of the coastal mountains.

The fire-prone and fire-dependent vegetation of the study area largely comprises montane sandstone fynbos (Rebelo et al. 2006). These are tall, medium-dense proteoid shrublands, with an ericoid-leaved shrub understorey (dominated by Ericaceae) and a prominent restioid (Restionaceae) component. Common overstorey proteoids are Leucadendron eucalyptifolium $(\mathrm{Le})$, L. uliginosum ( $\mathrm{Lu})$, Protea eximia $(\mathrm{Pe})$, P. mundii $(\mathrm{Pm})$ and $P$. neriifolia $(\mathrm{Pn})$ (nomenclature follows Rebelo 2001). Flowering times are: Le, July-October; $L u$, NovemberDecember; $P e$, July-December; Pm, January-September; and Pn, February-November (Rebelo 2001). However, there is a shift from winter-spring flowering to summer-autumn flowering both across and within lineages in the eastern-CFK (Cowling 1987), where $P n$ flowers in summer and Le in spring (Heelemann et al. 2008).

\section{Post-fire recruitment surveys}

147 In natural vegetation with known recent histories of fire occurrence, we undertook one-off 148 surveys (during 2007-2012) of recruitment success of overstorey proteoids ( $L e, L u, P e, P m, P n)$ 149 within four years post-fire $(1.9 \pm 0.7$ years, mean \pm standard deviation). We counted the number of proteoid seedlings (post-fire recruits) in relation to the number of burnt parents (pre-fire population) within belt transects $(2 \mathrm{~m} \times 30 \mathrm{~m})$. Proteoid seedling-parent counts are an established method for studying aspects of fynbos post-fire recruitment success (e.g. Bond 1980; Bond et al. 1984; van Wilgen \& Viviers 1985; Midgley 1989; Cowling \& Gxaba 1990; Heelemann et al. 2008). Previous studies largely surveyed proteoid densities in $1 \mathrm{~m}^{2}$ quadrats spaced $5 \mathrm{~m}$ apart along lines, but belt transects ( $2 \mathrm{~m}$ in width; Treurnicht et al. 2016) provide for more time- 
156

157

158

159

160

161

162

163

164

165

166

167

168

169

170

171

172

173

174

175

176

177

178

179

180

181

182

183

184

185

186

187

188

189

190

191

192

193

194

195

196

197

198

199

200

201

efficient data collection, particularly given low proteoid densities. We surveyed 26 sites throughout the study area (Table S1; Figure 1), each of which represented a particular fire or unique habitat (in terms of slope and/or aspect) within a fire. One or more proteoid species occurred at each site (Table S1) with site-species combinations providing 46 replicates for analysis. We surveyed 2-14 transects (recording all proteoid species present; Table S1) per survey site, aiming to record at least 30 parents and 30 seedlings per species at each site. However, at sites with low proteoid densities these numbers could not always be attained despite surveying more transects. Of the 46 site-species replicates sampled, six were winter burns, 20 spring, 12 summer and eight autumn burns. Fire return interval ( $\sim$ pre-fire vegetation age) ranged from 7-38 years, i.e. intervals where recruitment is unlikely to be constrained by seed shortages associated with juvenile proteoids (Kraaij et al. 2013c). We obtained rainfall figures (measured at the town of Plettenberg Bay) for a period of six months after each fire surveyed.

We combined the data of all transects within each site-species replicate and calculated for the latter the seedling-parent ratio as a measure of recruitment success. We were primarily interested in the effects of fire season $(n=46)$ on recruitment success, but considered other variables known to affect recruitment (Bond 1984; Bond et al. 1984; Heelemann et al. 2008), namely fire return interval (pre-fire vegetation age at the time of fire) $(n=21)$, post-fire age of the vegetation (at the time when recruitment was assessed) $(n=46)$, parent density $(n=33)$, post-fire rainfall (over six months post-fire) $(n=46)$ and species $(n=46)$.

We used a linear plus rule-based ensemble procedure 'RuleFit' with ten-fold crossvalidation (Friedman \& Popescu 2008) to determine the importance of the predictor variables listed above in affecting seedling-parent ratio. Predictor importance is expressed relative to the most important predictor and reported on a percentage scale. Predictor effects are shown using partial dependence plots; these show the marginal effect of a predictor on the response variable after taking account of the average effect of the other variables in the model (Friedman \& Popescu 2008). An advantage of using RuleFit compared to a standard regression method is that the most important predictor variables are automatically selected by the method, as are the important interactions (a consequence of the base-learners in the boosting step being decision trees). These are important considerations when (as here) the intention is to determine from the experimental data what the main predictors of the seedling-to-parent ratio are or might be. We subsequently used a generalized linear model (GLM) fitted by quasi-likelihood and the so-called square link (McCullagh \& Nelder 1989; Hilbe 2011), to test for the significance of the effect of fire season on seedling-parent ratio. Statistical analyses were done using R (R Development Core Team 2016).

\section{Seed planting experiment}

We conducted a seed planting experiment to assess the influence of planting season, intended to simulate fire season (see below; hereafter referred to as an effect of fire season) on germination and survival to one year post-planting of three common overstorey proteoid species $(\mathrm{Le}, \mathrm{Pm}$ and $P n)$ in the study area. We conducted the experiment at three spatially well-separated sites: 'West' $\left(33.98094^{\circ} \mathrm{S}, 23.20743^{\circ} \mathrm{E}\right.$, elevation $\left.312 \mathrm{~m}\right)$, 'Central' $\left(33.90880^{\circ} \mathrm{S}, 23.43462^{\circ} \mathrm{E}, 553 \mathrm{~m}\right)$, and 'East' $\left(33.96483^{\circ} \mathrm{S}, 24.26432^{\circ} \mathrm{E}, 488 \mathrm{~m}\right)$ (Figure 1). All three sites occurred at post-fire vegetation ages of $>10$ years, on gentle north-facing slopes. The experiment thus entailed three factors in a completely crossed design: (i) planting season - summer, autumn, spring and winter; (ii) site - West, Central and East; and (iii) species - Le, $P m$ and $P n$, the most common overstorey proteoids in the area. 
202

203

204

205

206

207

208

209

210

211

212

213

214

215

216

217

218

219

220

221

222

223

224

225

226

227

228

229

230

231

232

233

234

235

236

237

238

239

240

241

242

243

244

245

246

247

At each site, the vegetation in an area of $15 \mathrm{~m} \times 15 \mathrm{~m}$ was slashed at ground level and removed to simulate the effect of fire. The germination requirements of proteoids are wellunderstood and are strongly dependent on moist, cold $\left(1-11^{\circ} \mathrm{C}\right)$ conditions (in part provided by removal of the insulating effect of vegetation) rather than on the direct effects of fire (e.g. heat scarification or smoke/ash leachates) (Van Staden \& Brown 1977; Le Maitre 1990; Midgley \& Viviers 1990; Mustart \& Cowling 1991, 1993; Brown \& Botha 2004). Areas cleared of vegetation may thus be used to simulate post-fire environments in order to study proteoid recruitment dynamics (cf. Bond 1984; Midgley et al. 1989). Simulating fire by clearing vegetation furthermore precludes the introduction of unwanted variation in aspects of fires (e.g. fire intensity, which cannot be fully controlled during experimental burning) that are not the focus of the study. We treated the cleared area with a domestic disinfectant ("Jeyes Fluid" with active ingredients being tar acid, washed neutral oil and methanol, diluted at $60 \mathrm{ml}$ per 5 litre of water, as used in commercial farming of proteoids, K. Bezuidenhout pers. comm. 2010/06/01; with 30 litres of the solution applied to each site) to simulate the sterilising effect of fire on pathogens, notably the fungi Colletotrichum gloeosporoides and Phytophthora cinnamomi (Botha \& Le Maitre 1992). The cleared area included a $3 \mathrm{~m}$ buffer around the perimeter (to reduce edge- and shading effects) with the experimental site in the centre. Flower heads (seed cones) of the study species were harvested from local populations in the vicinity of the study sites one month prior to each of the four planting occasions. Cones were harvested from the current or previous season's crops and oven-dried at $40^{\circ} \mathrm{C}$ until seeds were released (Mustart \& Cowling 1993). Apparently viable (plump and unscarred) seeds were hand-sorted (Mustart \& Cowling 1991); about $90 \%$ of such sorted seeds will germinate in controlled conditions (Le Maitre 1990).

Each of the three experimental sites was divided into twelve plots (of $2.0 \mathrm{~m} \times 2.5 \mathrm{~m}$ each) and season allocated randomly to the plots (three plots per season). The seeds were planted on four occasions: in July 2010 (winter), October 2010 (spring), January 2011 (summer) and April 2011 (autumn). One month prior to the planting of seed, regrowth of vegetation was cleared again and disinfectant reapplied to the respective season's plots. Seeds were lightly pushed into the ground (such that the top parts of seeds were flush with the soil surface or slightly covered with soil; Mustart \& Cowling 1991, 1993), simulating the habit of Protea seeds to anchor and orientate optimally in the soil by means of specialised hairs (Rebelo 2001) and the depth of burial by scatter-hoarding rodents (Midgley et al. 2002). Seeds and seedlings were protected from small mammal and bird predation (Bond 1984; Le Maitre 1988) by exclosures made from bird mesh (13 mm gauge size, with negligible effects on micro-climate relevant to germination), closed at the top and pegged to the ground. Without exclosures, post-fire seed predation is very high $(80 \%$ over 15 weeks; Bond 1984), which would have precluded an experimental assessment of the effects of fire season on seedling recruitment. Seeds were planted in rows such that seeds within and between rows were $50 \mathrm{~mm}$ apart (Midgley et al. 1989; Mustart \& Cowling 1993) with 102 seeds of each species planted per plot. A total of 306 seeds of each species were planted per site per season, 1224 seeds per species per site, and a total number of 11016 seeds across sites, seasons and species. Germination and seedling survival were monitored during the first week of each month for one year after planting. A standard rain gauge was mounted $1.2 \mathrm{~m}$ above the ground at each site and rainfall measured monthly.

Probability of germination and survival to one year (hereafter referred to as 'recruitment') was the measure of interest and the focus of data analysis. We explored the effects of season, site and species on recruitment (at one year post-planting; expressed as a proportion of the number of

PeerJ reviewing PDF | (2017:02:16236:2:0:NEW 21 Jun 2017) 
248

249

250

251

252

253

254

255

256

257

258

259

260

261

262

263

264

265

266

267

268

269

270

271

272

273

274

275

276

277

278

279

280

281

282

283

284

285

286

287

288

289

290

seeds planted per species per plot), using a series of fixed-effects and mixed-effects logistic regression models (detailed in Table S2) using the binomial family and the logistic link, giving regression coefficients that represent log-odds. The random-effects structure of the mixed models best matched the design of the experiment, with plot exclosure nested in season, which was nested in plot, which was nested in site (i.e. 1|Site/Plot/Season/PlotExcl). We assessed the significance of effects using Wald tests (Harrell 2001; Agresti 2002). Replicates of planting season only covered one year of study for each level. It might therefore be argued that our results are only relevant to this period. The climatic conditions (rainfall and temperature) that prevailed during the course of the study were, however, within the norm for the area (Figure S1). We thus argue that our results are generally applicable to the area of study.

\section{Results}

\section{Post-fire recruitment surveys}

Seedling-parent ratios varied widely (0-43, coefficient of variation 115\%) within and among fire seasons, species and regions (Outeniqua vs. Tsitsikamma; Figure 1) (Figure 2). The RuleFit model fitted the data well (variance explained, $97.7 \%$; normalised root-mean-square error, 0.15 ; normalised standard deviation, 0.99). The model showed the most important variables affecting recruitment success to be species (estimated relative importance averaged over all predictions, $100 \%)$, parent density (56\%), post-fire vegetation age (55\%) and fire season (39\%), while postfire rainfall $(22 \%)$ and fire return interval (11\%) were unimportant (Figure 3). Autumn and spring fires resulted in better recruitment (of species combined) than winter and summer fires. Recruitment was negatively related to parent density at densities of $<6000$ parents/ha and positively related to the post-fire age ( $>26$ months) of the vegetation at the time of assessment. According to the GLM, fire season was not significant at the 5\% level in affecting post-fire recruitment success $\left(F_{3,42}=2.53, P=0.07\right.$; detailed model output in Table S3).

\section{Seed planting experiment}

Total rainfall during the 21-month course of the experiment was comparable among sites (West $1315 \mathrm{~mm}$, Central $1371 \mathrm{~mm}$, East $1397 \mathrm{~mm}$ ) and not indicative of a strong rainfall gradient. Overall, 38\% of planted seeds ( Le 20\%, Pm 45\%, Pn 50\%) germinated, and 84\% of these germinants (Le 70\%, Pm 86\%, Pn 90\%) survived. Germination was limited to the cooler months (March/April-November) with seeds planted in spring, autumn and winter mostly germinating within two months post-planting (Figure S2). In contrast, seeds planted in summer only germinated four to five months post-planting with the advent of cooler conditions. Additionally, a small proportion of winter- and spring-plantings germinated during their second cold season post-planting. We observed no obvious association between monthly rainfall and the timing of germination (or mortality) in our experiment (Figure S2).

Recruitment differed significantly among planting seasons, sites and species, with $L e$ recruitment being poorer than that of $P m$ and $P n$. Recruitment pooled across sites and species was highest in winter-plantings $(37.9 \pm 4.0 \%$, mean $\pm \mathrm{SE})$, decreasing through autumn- $(35.5 \pm$ $3.9 \%)$ and summer- $(29.8 \pm 2.7 \%)$ to spring-plantings $(26.3 \pm 3.4 \%)$ (Figs $3 \& S 3)$. Significant interactions occurred among the experimental factors (Table 1; Figure 4), i.e. the effect of planting seasonality on recruitment success was not consistent among species within sites, nor 
291 among sites within species. Recruitment responses at the western and central sites were more 292 similar than at the eastern site.

293

\section{Discussion}

\section{Germination cues: moisture and temperature}

296 Levels of proteoid germination (20-50\%) in our seed planting experiment were comparable to 297 those in other field studies (c. 10-60\%, Cowling \& Lamont 1987; 24\%, Midgley et al. 1989; 45 298 80\%, Mustart \& Cowling 1993) and under optimal laboratory conditions (30-60\%, Van Staden \& 299 Brown 1977). Distinguishing between fertile and infertile seeds is problematic in Leucadendron, 300 unlike in Protea (Van Staden \& Brown 1977). Ineffective sorting of Leucadendron 301 eucalyptifolium seeds may thus have accounted for their comparatively poor germination in our 302 experiment, although poor recruitment does not appear to be the norm in Leucadendron in the 303 field, as seen from our post-fire recruitment surveys.

We asked whether the establishment of obligate reseeding shrubs would be constrained by rainfall in aseasonal environments as elsewhere in Mediterranean-climate shrublands where seasonal droughts are a feature (Bond 1984; Lamont et al. 1991a; Moreno et al. 2011; Céspedes et al. 2012; Mustart et al. 2012). Proteoids show a summer drought-avoiding dormancy in many areas (Deall \& Brown 1981; Bond 1984; Midgley et al. 1989) with germination following a temperature plus moisture cue (Van Staden \& Brown 1977) which is met by the cold and wet conditions of winter under Mediterranean climates (Cowling \& Lamont 1987; Le Maitre 1988, 1990; Mustart \& Cowling 1991). However, we observed no obvious association between (i) monthly rainfall and the timing of germination (or mortality) in our experiment, or (ii) post-fire rainfall and recruitment success in our post-fire surveys, suggesting that post-fire rainfall per se is seldom limiting to recruitment success in the study area. We could, however, not assess potential effects of fire season and post-fire climatic conditions on very early mortality of seeds exposed on the soil surface, due to constraints of monitoring frequency and the need to secure seed positions through 'planting' in our experiment.

318

In the semi-arid Swartberg Mountains (inland of the study area, where rainfall is also associated with higher temperatures and lower humidity; Seydack et al. 2007) germination of proteoids was strongly correlated with temperature but not with monthly rainfall (Midgley et al. 1989). We observed a delay in germination following summer-planting which appeared to be due to the absence of low temperatures (minimum monthly temperature $<10^{\circ} \mathrm{C}$ ) that are typically needed to stimulate germination in proteoids $\left(5^{\circ} \mathrm{C}\right.$, Van Staden \& Brown $1977 ; 10^{\circ} \mathrm{C}$, Mustart \& Cowling 1991) and Erica (Moreno et al. 2011) elsewhere. In the aseasonal shrublands of southeastern-Australia, ambient temperature also strongly controls germination, with high summer temperatures presumably imposing secondary dormancy on seeds irrespective of rainfall (Bradstock \& Bedward 1992). During mid-summer, germination thus appears to be prevented or to fail (germinants succumbing to desiccation; Mustart et al. 2012) due to moisture deficits associated with high temperatures rather than an absence of rainfall in aseasonal climates, as opposed to the combination in Mediterranean climates (Deall \& Brown 1981).

\section{Effect of fire season on recruitment}


334 We found that fire season or its simulation had little consistent effect on post-fire recruitment 335 success, which is in strong contrast to the consistent responses of proteoids to fire season in 336 many southern hemisphere shrublands (Midgley 1989). Under more seasonal (winter rainfall and

337

338

339

340

341

342

343

344

345

346

347

348

349

350

351

352

353

354

355

356

357

358

359

360

361

362

363

364

365

366

367

368

369

370

371

372

373

374

375

376

377

378

379

summer drought) and less equable climates, spring and summer fires resulted in increased pregermination mortality of proteoid seed due to extended post-fire exposure to predation and decay (Bond 1984; Bond et al. 1984; Enright \& Lamont 1989; Midgley et al. 1989). Under a regime of evenly distributed rainfall, however, favourable conditions for germination after spring or summer fires are likely to occur sooner or more regularly than under winter-rainfall or semi-arid regimes. Under aseasonal climates, the germination delay is thus contracted and season of fire presumably less influential on post-fire recruitment success. It is unlikely that predator exclosures used in this study would have materially influenced our findings, as the effect of seed predation on disparate recruitment success among fire seasons observed in winter rainfall fynbos relate more to the duration of seed exposure to predation (Bond 1984; Le Maitre 1988) than to the seasonality of seed exposure and seasonality of rodent consumption (Holmes 1990; Rusch et al. 2014). Seed consumption by rodents is furthermore expected to be less seasonal in eastern fynbos where plant phenology (and thus seed production) is less seasonal (Cowling 1987).

Recruitment success was not consistently superior after fire in any particular season in our study. Trends from our post-fire recruitment surveys (peaks in recruitment success after autumn and spring fires) differed from those of the seed planting experiment (peaks after winter and autumn fire simulation), while results furthermore varied greatly within and among species and sites ( habitat types with diverse soils, slopes and aspects) in both these datasets.

Collectively, this suggests that seasonal patterns in post-fire recruitment are weak in eastern coastal fynbos. In eastern inland fynbos, in sites drier than our coastal ones, Heelemann et al. (2008) observed peaks in recruitment after autumn and spring fires, similar to results from our post-fire recruitment surveys, and explained these on the basis of the bimodal (spring-autumn) rainfall regime of the area. However, we question whether this simple relationship adequately explains, and provides evidence of, seasonality in post-fire recruitment in eastern coastal fynbos, particularly in light of a lack of correlation between germination and rainfall in both eastern coastal fynbos (see above) and further inland (Midgley et al. 1989). Moreover, rainfall in the study area is not strictly bimodal and may be more appropriately described as aseasonal with marked variation in seasonality among years (cf. Figure S1).

We maintain that seasonal patterns in post-fire recruitment are weak in eastern coastal fynbos; good (or poor) recruitment may be expected at any time of the year and may vary considerably between years and habitat types. A weak seasonal response in recruitment is plausible under an equable, coastal climate with year-round rainfall and is in accordance with the lack of seasonality recorded both in weather conditions conducive to fire (Kraaij et al. 2013a) and historical fire occurrence (Kraaij et al. 2013b) in the area. In the analogous aseasonal shrublands of southeastern-Australia, the effects of fire season on recruitment are equally unpredictable, given the high level of year to year variation in seasonal rainfall (Bradstock \& Bedward 1992). These authors suggested that, in the longer term, the timing of fire relative to sequences of wet and dry years may be just as important as fire season in its effect on proteoid populations. Accordingly, the interaction between rainfall variability and fire season was shown to disparately affect recruitment of different species of reseeding shrubs in the Mediterranean Basin (Moreno et al. 2011).

\section{Effects of other factors on recruitment}

PeerJ reviewing PDF | (2017:02:16236:2:0:NEW 21 Jun 2017) 
380 Our results suggest that recruitment may also vary according to species, the density of parent 381 plants, and the post-fire age of the vegetation at the time of assessment. Large variation in post382 fire recruitment, as observed in our study (Figure 2), is characteristic of fynbos proteoids (van 383 Wilgen \& Viviers 1985; Cowling \& Gxaba 1990), even within favourable fire seasons (post384 summer/autumn fire seedling-parent ratios of 12-19, Bond 1980; 0-21, Bond et al. 1984; 3-15, van Wilgen \& Viviers 1985; 0-9, Le Maitre 1988), and may be caused by a variety of factors. In our study, individual species differed in their recruitment responses (Bond et al. 1984; Midgley et al. 1989), which may be related to wide variation (among species and/or habitats) in postemergence desiccation tolerance (Mustart et al. 2012). Large variability in regeneration within and between species and fire events (cf. Moreno et al. 2011), suggests that generalisations based on studies of single species or fires should be treated with considerable caution.

In our study, parent density had a greater effect on recruitment success than fire season

391

392

393

394

395

396

397

398

399

400

401

402

403

404

405

406

407

408

409

410

411

412

413

414

415

416

417

418

419

420

421

422

423

424

had. Other studies have found proteoid parent density either to have no effect (Cowling \& Gxaba 1990), or more (Le Maitre 1988) or less (Bond et al. 1984; Midgley 1989; Esler \& Cowling 1990) effect, than that of fire season. Negative effects of parent density on recruitment have been ascribed to suppressed seed production (Bond et al. 1984), although evidence is conflicting at the individual and population levels (Esler \& Cowling 1990; Treurnicht et al. 2016).

Recruitment success in our study increased with post-fire vegetation ages (at the time of assessment) exceeding 26 months. This does not support the notion of increases in seedling mortality with post-fire vegetation age (Bond et al. 1984). Instead, decay of parent skeletons may have resulted in undercounting of parents (and thus overestimation of seedling-parent ratios) in older post-fire ages. Alternatively, small size of seedlings in very young post-fire ages may have resulted in their being undercounted. Restricting the observation window to 1-2 years post-fire should reduce this source of noise in the data. Fire return interval may also affect recruitment success (Bond 1980; Treurnicht et al. 2016) through its effect on seed availability (related to plant maturation rates; Muir et al. 2014), but had no effect in our study as we deliberately excluded data of short ( $<7$ year) interval fires, known to inhibit recruitment (Kraaij et al. 2013c).

\section{Management implications}

Prescribed burning is seen as an important management option in fire-prone shrublands globally (van Wilgen et al. 1994; Morrison et al. 1996), but its use is constrained by many factors, including the need to burn within acceptable limits of season, frequency and intensity (Bradstock et al. 2002; van Wilgen et al. 2011). The weak and varied response of proteoid recruitment to fire season implies that burning does not have to be limited to particular seasons in eastern coastal fynbos, and this would remove at least one constraining factor, which should improve the chances of carrying out successful burns. However, various other constraints on fire management remain. Fire return intervals should allow for adequate seed production in slow-maturing obligate reseeders to ensure post-fire regeneration (Kraaij et al. 2013c; Muir et al. 2014). Fire intensity needs to be sufficiently high to stimulate seed release and germination in serotinous (Bradstock \& O'Connell 1988; Midgley \& Viviers 1990) and large or hard-coated, soil-stored seeds (Jefferey et al. 1988; Bond et al. 1990; Knox \& Clarke 2006), but not too extreme that all seeds of fine-seeded species in the surface layers of the soil be killed (Bond et al. 1999). Additionally, there is evidence that variation in fire regimes is necessary to maintain plant diversity in the landscape (Thuiller et al. 2007; Gill \& McCarthy 1998), and particularly in an unpredictable, aseasonal environment. 
425

426

427

428

429

430

431

432

433

434

435

436

437

438

439

440

441

442

443

444

445

446

447

448

449

450

451

452

453

454

455

456

457

458

459

460

461

462

463

464

465

466

467

468
Ecological requirements of fire regimes furthermore have to be traded off with the need for safety of human lives and assets (commercial timber plantations, in particular in the study area; Kraaij et al. 2011), which often present considerable management challenges (Morrison et al. 1996; van Wilgen et al. 2012). The incidence of weather conditions that would meet both the ecological need for fire intensity and human needs for fire safety is typically low in fynbos environments (c. 10\% of days annually; van Wilgen \& Richardson 1985). Implementation of further restrictions based on fire season (arising from research suggesting that fynbos recruitment is highly seasonal; Bond et al. 1984; van Wilgen \& Viviers 1985) made prescribed burning of fynbos at a large scale unattainable (van Wilgen 2009). The lack of a seasonal restraint on burning in eastern coastal fynbos therefore has significant and encouraging management implications in affording more flexibility for fire management in this area, although the ecological need for sufficient fire intensity remains.

Even though wildfires almost completely dominated the recent fire history of the area (Kraaij et al. 2013b), prescribed burning remains necessary: (i) in key locations to reduce the risk of fire spreading from fynbos to adjacent timber plantations (Kraaij, et al. 2011); (ii) along the wildland-urban interface (Radeloff et al. 2005; van Wilgen et al. 2012); (iii) as a tool in the management of invasive alien plants (Roura-Pascual et al. 2009; van Wilgen et al. 2016); and (iv) to rejuvenate fragments of fire-dependent vegetation where ignition sources have been reduced or eliminated by transformation of the surrounding landscape. Our findings suggest that prescribed burning may be done in these instances during any season within a framework of adaptive management (van Wilgen et al. 2011). Managers furthermore do not have to allocate large amounts of resources to fight wildfires that are burning in the 'wrong' season and may conduct back-burns to contain wildfires during any season. In conclusion, because the seasonal occurrence of fires may vary over the geographical range of a particular vegetation type, the responses of the vegetation to fires in different seasons clearly need to be documented across the geographical extent of the vegetation type to refine guidelines for fire management.

\section{Acknowledgements}

We thank Johan Huisamen, Johan Baard and George Sass for field assistance; Jan Vlok, Yvette van Wijk, Karien Bezuidenhout, Penny Mustart, Andrew Latimer, Anthony Hitchcock and Tony Rebelo for advice with the germination experiment; Andrew West for sharing seedling-parent ratio survey data for two sites; Jeanette Pauw for initial statistical advice; Thertius Notley for weather records of Keurboomsrivier Plantation; the South African Weather Service for weather records; and South African National Parks, Eastern Cape Parks and Tourism Board, and Mountain to Ocean Forestry for permission to work on land under their management. David le Maitre and two anonymous reviewers provided useful comments which led to the improvement of this manuscript.

\section{References}

Agresti A (2002) Categorical data analysis. John Wiley \& Sons, New York.

Bell DT (2001) Ecological response syndromes in the flora of southwestern western Australia: fire resprouters versus reseeders. The Botanical Review 67(4):417-440.

Bond WJ (1980) Fire and senescent fynbos in the Swartberg, Southern Cape. South African Forestry Journal 114:68-71. 
469

470

471

472

473

474

475

476

477

478

479

480

481

482

483

484

485

486

487

488

489

490

491

492

493

494

495

496

497

498

499

500

501

502

503

504

505

506

507

508

509

510

511

512
Bond WJ (1981) Vegetation gradients in the southern Cape Mountains. MSc thesis, University of Cape Town, Cape Town.

Bond WJ (1984) Fire survival of Cape Proteaceae - influence of fire season and seed predators. Vegetatio 56:65-74.

Bond WJ, Honig M, Maze KE (1999) Seed size and seedling emergence: an allometric relationship and some ecological implications. Oecologia 120:132-136.

Bond WJ, Le Roux D, Erntzen R (1990) Fire intensity and regeneration of myrmecochorous Proteaceae. South African Journal of Botany 56:326-330.

Bond WJ, Vlok J, Viviers M (1984) Variation in seedling recruitment of Cape Proteaceae after fire. Journal of Ecology 72:209-221.

Botha SA, Le Maitre DC (1992) Effects of seed and seedling predation by small mammals on seedling recruitment of Protea neriifolia in Swartboskloof, Cape Province. South African Journal of Zoology 27(2):60-69.

Bradstock RA, Bedward M (1992) Simulation of the effect of season of fire on post-fire seedling emergence of two Banksia species based on long-term rainfall records. Australian Journal of Botany 40(1):75-88.

Bradstock RA, O’Connell MA (1988) Demography of woody plants in relation to fire: Banksia ericifolia L.f. and Petrophile pulchella (Schrad) R. Br. Austral Ecology 13:505-518.

Bradstock RA, Williams JE, Gill MA (2002) Flammable Australia: the fire regimes and biodiversity of a continent. Cambridge University Press, Cambridge.

Brown NAC, Botha PA (2004) Smoke seed germination studies and a guide to seed propagation of plants from the major families of the Cape Floristic Region, South Africa. South African Journal of Botany 70(4):559-581.

Céspedes B, Torres I, Luna B, Pérez B, Moreno JM (2012) Soil seed bank, fire season, and temporal patterns of germination in a seeder-deominated Mediterranean shrubland. Plant Ecology 213:383-393.

Cowling RM (1987) Fire and its role in coexistence and speciation in Gondwanan shrublands. South African Journal of Science 83:106-112.

Cowling RM, Gxaba T (1990) Effects of a fynbos overstorey shrub on understorey community structure: implications for the maintenance of community-wide species richness. South African Journal of Ecology 1:1-7.

Cowling RM, Lamont BB (1987) Post-fire recruitment of four co-occurring Banksia species. Journal of Applied Ecology 24:645-658.

Deall GB, Brown NAC (1981) Seed germination in Protea magnifica Link. South African Journal of Science 77:175-176.

Domínguez L, Calvo L, Luis E (2002) The impact of wildfire season on regeneration of Quercus pyrenaica forest and Pinus sp. stands. Journal of Mediterranean Ecology 3:47-54.

Driscoll DA, Lindenmayer DB, Bennett AF, Bode M, Bradstock RA, Cary GJ, Clarke MF, Dexter N, Fensham R, Friend G, Gill M, James S, Kay G, Keith DA, MacGregor C, Russell-Smith J, Salt D, Watson JEM, Williams RJ, York A (2010) Fire management for biodiversity conservation: key research questions and our capacity to answer them. Biological Conservation 143:1928-1939.

Enright NJ, Lamont BB (1989) Seed banks, fire season, safe sites and seedling recruitment in five co-occurring Banksia species. Journal of Ecology 77:1111-1122. 
513 Enright NJ, Marsula R, Lamont BB, Wissel C (1998) The ecological significance of canopy seed

514

515

516

517

518

519

520

521

522

523

524

525

526

527

528

529

530

531

532

533

534

535

536

537

538

539

540

541

542

543

544

545

546

547

548

549

550

551

552

553

554

555

556

557

558 storage in fire-prone environments: a model for non-sprouting shrubs. Journal of Ecology 86:946-959.

Esler KJ, Cowling RM (1990) Effects of density on the reproductive output of Protea lepidocarpodendron. South African Journal of Botany 55(1):29-33.

Friedman JH, Popescu BE (2008) Predictive learning via rule ensembles. The Annals of Applied Statistics 2(3):916-954.

Gill AM (1975) Fire and the Australian flora - a review. Australian Forestry 38:4-25.

Gill AM, McCarthy MA (1998) Intervals between prescribed fires in Australia: what intrinsic variation should apply? Biological Conservation 85:161-169.

Harrell FE Jr (2001) Regression modelling strategies: with applications to linear models, logistic regression, and survival analysis. Springer-Verlag, New York.

Heelemann S, Proches S, Rebelo AG, van Wilgen BW, Porembski S, Cowling RM (2008) Fire season effects on the recruitment of non-sprouting serotinous Proteaceae in the eastern (bimodal rainfall) fynbos biome, South Africa. Austral Ecology 33(2):119-127.

Hilbe JM (2011) Generalized linear models. In: Lovric M, editor. International encyclopaedia of statistical science, pp. 591-596. Springer Berlin, Heidelberg. doi:http://doi.org/10.1007/978-3-642-04898-2_273

Holmes PM (1990) Dispersal and predation of alien Acacia seeds: effects of season and invading stand density. South African Journal of Botany 56(4):428-434.

Jefferey DJ, Holmes PM, Rebelo AG (1988) Effects of dry heat on seed germination in selected indigenous and alien legume species in South Africa. South African Journal of Botany 54:28-34.

Jordaan PG (1949) Aantekeninge oor die voortplanting en brandperiodes van Protea mellifera Thunb. Journal of South African Botany 15:121-125.

Keeley JE (2006) Fire management impacts on invasive plants in the western United States. Conservation Biology 20:375-384.

Keeley JE, Pausas JG, Rundel PW, Bond WJ, Bradstock RA (2011) Fire as an evolutionary pressure shaping plant traits. Trends in Plant Science 16(8):406-411.

Knox KJE, Clarke PJ (2006) Fire season and intensity affect shrub recruitment in temperate sclerophyllous woodlands. Oecologia 149:730-739.

Kraaij T, Cowling RM, van Wilgen BW (2011) Past approaches and future challenges to the management of fire and invasive alien plants in the new Garden Route National Park. South African Journal of Science 107(9/10):15-25. doi:10.4102/sajs.v107i9/10.633

Kraaij T, Cowling RM, van Wilgen BW (2013a) Lightning and fire weather in eastern coastal fynbos shrublands: seasonality and long-term trends. International Journal of Wildland Fire 22(3):288-295. doi:10.1071/WF11167.

Kraaij T, Baard JA, Cowling RM, van Wilgen BW, Das S (2013b) Historical fire regimes in a poorly-understood, fire-prone ecosystem: eastern coastal fynbos. International Journal of Wildland Fire 22(3):277-287. doi:10.1071/WF11163.

Kraaij T, Cowling RM, van Wilgen BW, Schutte-Vlok A-L (2013c) Proteaceae juvenile periods and post-fire recruitment as indicators of minimum fire return interval in eastern coastal fynbos. Applied Vegetation Science 16:84-94. doi:10.1111/j.1654-109X.2012.01209.x.

Kruger FJ, Bigalke RC (1984) Fire in fynbos. In: Booysen PV, Tainton NM, editors. Ecological effects of fire in South African ecosystems. Ecological Studies 48:67-114. Berlin: Springer-Verlag. 
559 Lamont BB, Connell SW, Bergl SM (1991a) Seed bank and population dynamics of Banksia

560

561

562

563

564

565

566

567

568

569

570

571

572

573

574

575

576

577

578

579

580

581

582

583

584

585

586

587

588

589

590

591

592

593

594

595

596

597

598

599

600

601

602

603

604 cuneata: the role of time, fire and moisture. Botanical Gazette 152(1):114-122.

Lamont BB, Le Maitre DC, Cowling RM, Enright NJ (1991b) Canopy seed storage in woody plants. Botanical Review 57(4):277-317.

Le Maitre DC (1988) The effects of parent density and season of burn on the regeneration of Leucadendron laureolum (Proteaceae) in the Kogelberg. SA J Bot 54(6): 581-584.

Le Maitre DC (1990) The influence of seed ageing on the plant on seed germination in Protea neriifolia. South African Journal of Botany 56(1):49-53.

McCullagh P, Nelder JA (1989) Generalized linear models. London: Chapman and Hall.

Midgley JJ (1988) Mortality of Cape Proteaceae seedlings during their first summer. South African Forestry Journal 145:9-12.

Midgley JJ (1989) Season of burn of serotinous fynbos Proteaceae: a critical review and further data. South African Journal of Botany 55:165-170.

Midgley JJ, Viviers M (1990) The germination of seeds from heated serotinous cones of eight shrubland species. South African Forestry Journal 155:5-9.

Midgley JJ, Hoekstra T, Bartholomew R (1989) The effects of date of planting on field establishment of serotinous Cape Proteaceae. Vegetatio 79:185-192.

Midgley JJ, Anderson B, Bok A, Fleming T (2002) Scatter-hoarding of Cape Proteaceae nuts by rodents. Evolutionary Ecology Research 4:623-626.

Moreno JM, Zuazua E, Pérez B, Luna B, Velasco A, Resco de Dios V (2011) Rainfall patterns after fire differentially affect the recruitment of three Mediterranean shrubs. Biogeosciences 8:3721-3732.

Morrison DA, Buckney RT, Bewick BJ (1996) Conservation conflicts over burning bush in south-eastern Australia. Biological Conservation 76:167-175.

Muir AM, Vesk PA, Hepworth G (2014) Reproductive trajectories over decadal time-spans after fire for eight obligate-seeder shrub species in south-eastern Australia. Australian Journal of Botany 62:369-378.

Mustart PJ, Cowling RM (1991) Seed germination of four serotinous Agulhas Plain Proteaceae. South African Journal of Botany 57(6):310-313.

Mustart PJ, Cowling RM (1993) Effects of soil and seed characteristics on seed germination and their possible roles in determining field emergence patterns of four Agulhas Plain (South Africa) Proteaceae. Canadian Journal of Botany 71:1363-1368.

Mustart PJ, Rebelo AG, Juritz J, Cowling RM (2012) Wide variation in post-emergence desiccation tolerance of seedlings of fynbos proteoid shrubs. South African Journal of Botany 80(1):110-117.

Myers N, Mittermeier RA, Mittermeier CG, Da Fonseca GAB, Kent J (2000) Biodiversity hotspots for conservation priorities. Nature 403:853-858.

R Development Core Team (2016) R: a language and environment for statistical computing [Computer software manual]. Vienna, Austria. Retrieved from http://www.R-project.org (ISBN 3-900051-07-0 (R version 3.3.2 Patched (2016-11-24 r71690) for Windows [32/64 bit])).

Radeloff VC, Hammer RB, Stewart SI, Fried JS, Holcomb SS, McKeefry JF (2005) The wildland-urban interface in the United States. Ecological Applications 15(3):799-805.

Roura-Pascual N, Richardson DM, Krug RM, Brown A, Chapman RA, Forsyth GG, Le Maitre DC, Robertson MP, Stafford L, van Wilgen BW, Wannenburgh A, Wessels N (2009) Ecology and management of alien plant invasions in South African fynbos: 
605

606

607

608

609

610

611

612

613

614

615

616

617

618

619

620

621

622

623

624

625

626

627

628

629

630

631

632

633

634

635

636

637

638

639

640

641

642

643

644

645

646

647

648

accommodating key complexities in objective decision making. Biological Conservation 142(8):1595-1604.

Rebelo T (2001) Sasol Proteas. A field guide to the Proteas of southern Africa. Fernwood Press in Association with the National Botanical Institute, Cape Town.

Rebelo AG, Boucher C, Helme N, Mucina L, Rutherford MC (2006) Fynbos biome. In: Mucina L, Rutherford MC, editors. The Vegetation of South Africa, Lesotho and Swaziland, Strelitzia 19:158-159. South African National Biodiversity Institute, Pretoria.

Rusch UD, Midgley JJ, Anderson B (2014) Seasonal fluctuations in rodent seed caching and consumption behaviour in fynbos shrublands: implications for fire management. South African Journal of Botany 93:217-221.

Schulze BR (1965) Climate of South Africa. Part 8. General Survey. Weather Bureau, Department of Transport, Pretoria, South Africa.

Seydack AHW, Bekker SJ, Marshall AH (2007) Shrubland fire regime scenarios in the Swartberg Mountain Range, South Africa: implications for fire management. International Journal of Wildland Fire 16:81-95.

Southwood AJ (1984) Policy memorandum: Tsitsikamma mountain catchment area. Forestry Branch, Department of Environment Affairs, Knysna, South Africa.

Thuiller W, Slingsby JA, Privett SDJ, Cowling RM (2007) Stochastic species turnover and stable coexistence in a species-rich, fire-prone plant community. PLoS ONE 2(9):e938. doi:10.1371/journal.pone.0000938

Treurnicht M, Pagel J, Esler KJ, Schutte-Vlok AL, Nottebrock H, Kraaij T, Rebelo AG, Schurr FM (2016) Environmental drivers of demographic variation across the global geographical range of 26 plant species. Journal of Ecology 104:331-342. doi:10.1111/1365-2745.12508

Van Staden J, Brown NAC (1977) Studies on the germination of South African Proteaceae - a review. Seed Science and Technology 5:633-643.

van Wilgen BW (1984) Fire climates in the southern and western Cape Province and their potential use in fire control management. South African Journal of Science 80:358-362.

van Wilgen BW (2009) The evolution of fire and invasive alien plant management practices in fynbos. South African Journal of Science 105:1-8.

van Wilgen BW, Richardson DM (1985). Factors influencing burning by prescription in mountain fynbos catchment areas. South African Forestry Journal 134:22-32.

van Wilgen BW, Viviers M (1985) The effect of season of fire on serotinous Proteaceae in the Western Cape and the implications for fynbos management. South African Forestry Journal 133:47-53.

van Wilgen BW, Fill JM, Baard JA, Cheney C, Forsyth AT, Kraaij T. 2016. An assessment of the historical and projected future costs and effectiveness of invasive alien plant control in protected areas in the Cape Floristic Region. Biological Conservation 200:168-177. http://dx.doi.org/10.1016/j.biocon.2016.06.008

van Wilgen BW, Forsyth GG, Prins P (2012) The management of fire-adapted ecosystems in an urban setting: the case of Table Mountain National Park, South Africa. Ecology and Society 17(1):8. http://dx.doi.org/10.5751/ES-04526-170108.

van Wilgen BW, Govender N, Forsyth GG, Kraaij T (2011) Towards adaptive fire management for biodiversity conservation: experience in South African National Parks. Koedoe 53(2):Art. \#982, 9 pages, doi:10.4102/koedoe.v53i2.982. 
649 van Wilgen BW, Richardson DM, Seydack AHW (1994) Managing fynbos for biodiversity: 650 constraints and options in a fire-prone environment. South African Journal of Science 651

652 90:322-329. 
653 Table 1. Type II Wald $\chi^{2}$ tests of the effects of planting season, species, and site on recruitment

654

655

656

\begin{tabular}{lccc}
\hline & Wald $\chi^{2}$ & df & $\operatorname{Pr}\left(>\chi^{2}\right)$ \\
\hline Season & 42.7 & 3 & $<0.001$ \\
Species & 713.2 & 2 & $<0.001$ \\
Site & 45.7 & 2 & $<0.001$ \\
Season $\times$ Species & 105.4 & 6 & $<0.001$ \\
Season $\times$ Site & 34.5 & 6 & $<0.001$ \\
Species $\times$ Site & 67.2 & 4 & $<0.001$ \\
Season $\times$ Species $\times$ Site & 177.7 & 12 & $<0.001$ \\
\hline
\end{tabular}
on a generalized linear mixed-effects logistic regression model. (measured as survival at one year post-planting as a proportion of seeds planted) based 
658

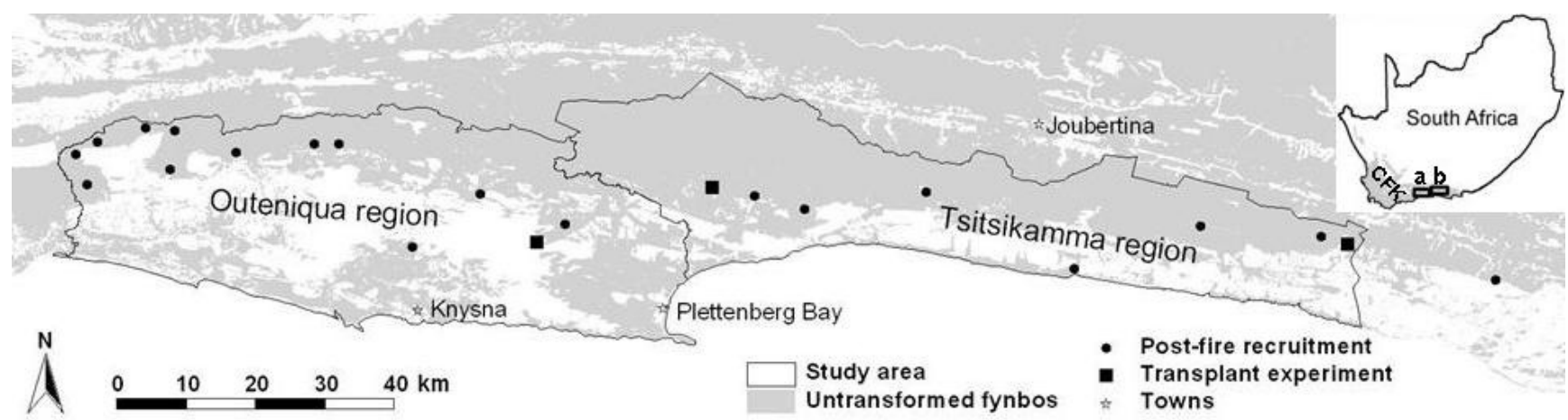

661 Figure 1. Map of the study area. Locations of the sites where post-fire recruitment surveys 662 (multiple sites in close proximity may not be discernible at this scale; see also Table S1) and a 663 seed planting experiment were conducted. The study area is divided into the Outeniqua and 664 Tsitsikamma regions (a and $\mathbf{b}$ in insert, respectively), the Keurbooms River being the divide 665 between these mountain ranges. The insert shows the location of the study area in relation to the 666 Cape Floral Kingdom (CFK, grey-shaded) and South Africa. 


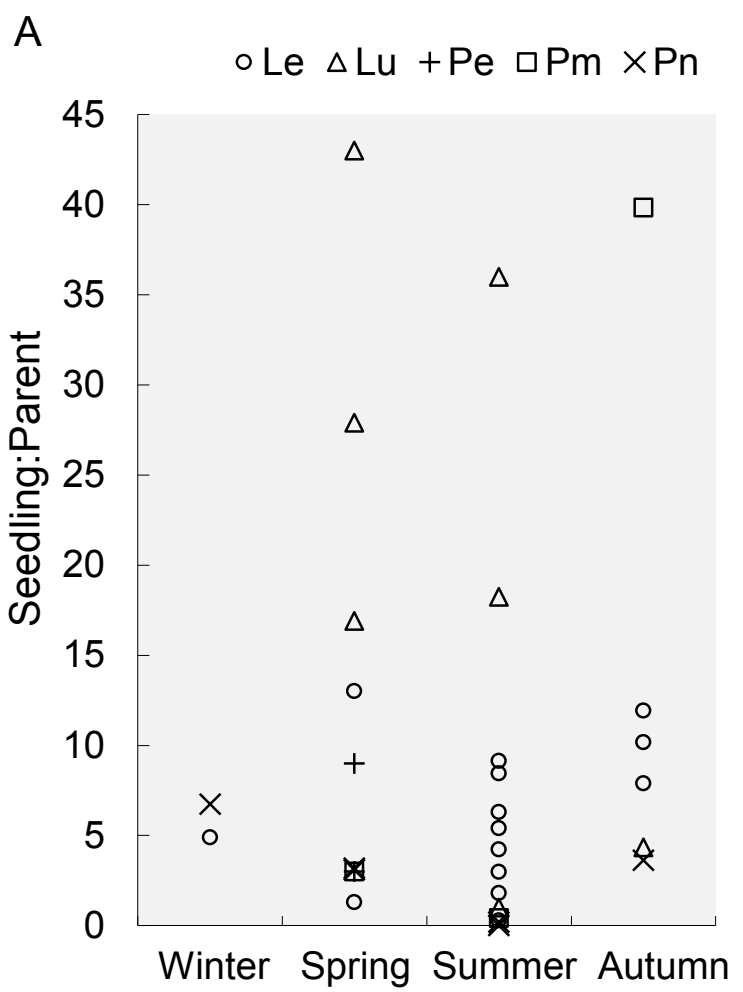

Fire season
Fire season

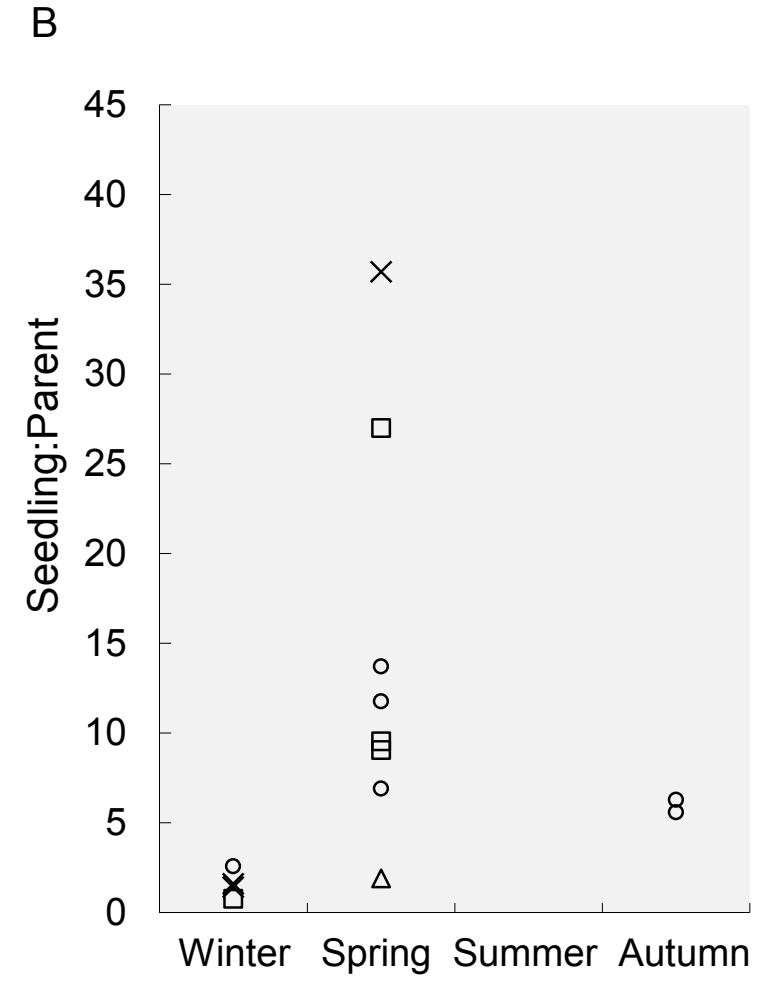

Figure 2. Recruitment success after fires in different seasons. Recruitment success, expressed as seedling-parent ratio, is shown for different proteoid species (Le, Leucadendron eucalyptifolium; Lu, L. uliginosum; Pe, Protea eximia; Pm, P. mundii; Pn, P. neriifolia) after fires in different seasons. We distinguish between two regions, (A) Outeniqua and (B) Tsitsikamma, in the study area. 

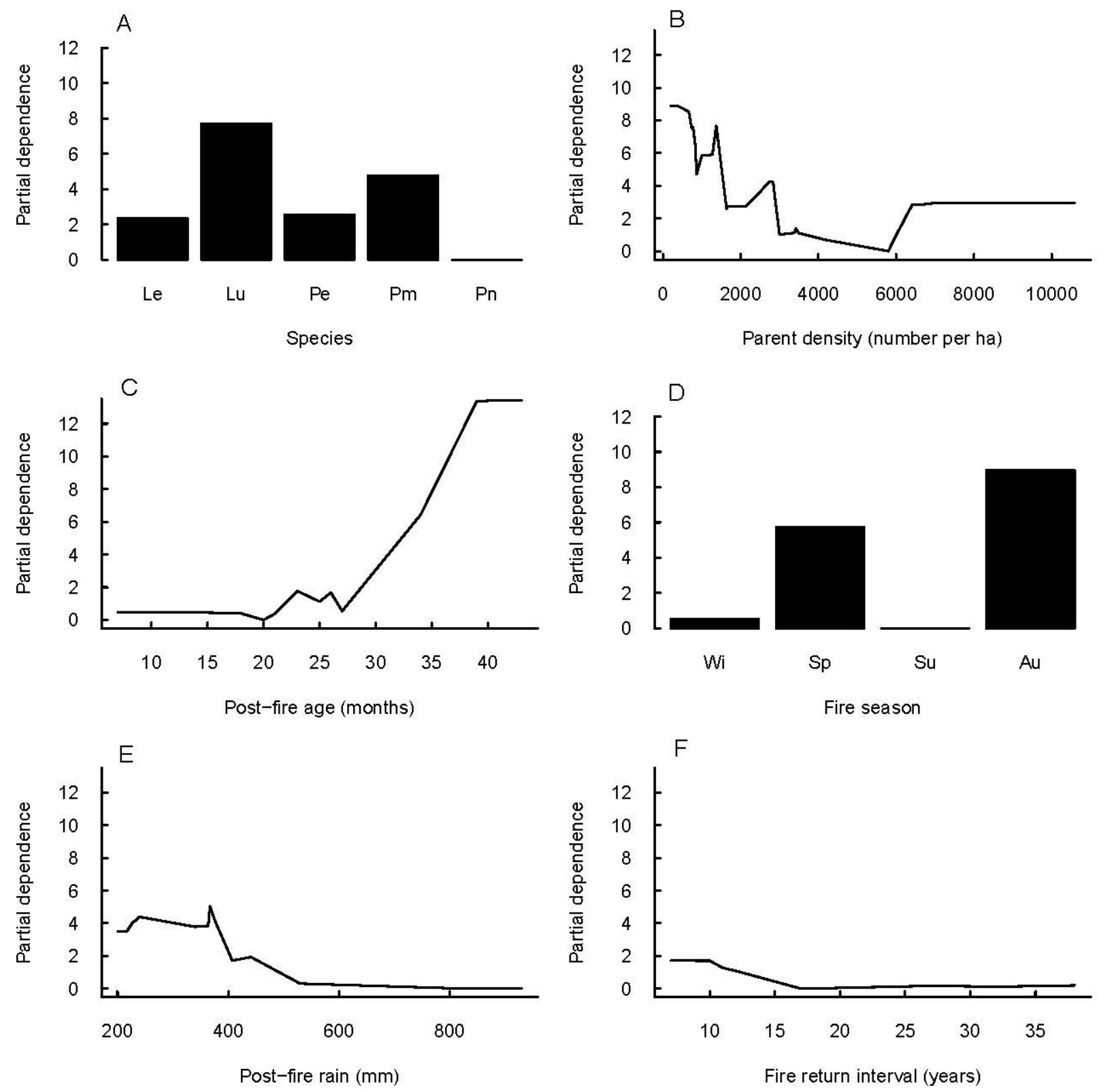

Figure 3. Partial dependence of post-fire recruitment success on predictor variables. Plots of partial dependence of post-fire recruitment success (measured as seedling-parent ratio) on predictor variables (A-F, in decreasing order of importance) as modelled by a linear plus rulebased ensemble procedure (RuleFit): (A) species (Le, Leucadendron eucalyptifolium; Pe, Protea eximia; Pm, P. mundii; Pn, P. neriifolia), (B) parent density, (C) post-fire vegetation age at the time of assessment, (D) fire season (Wi, winter; Sp, spring; Su, summer; Au, autumn), (E) postfire rainfall (during six months post-fire) and (F) fire return interval. 


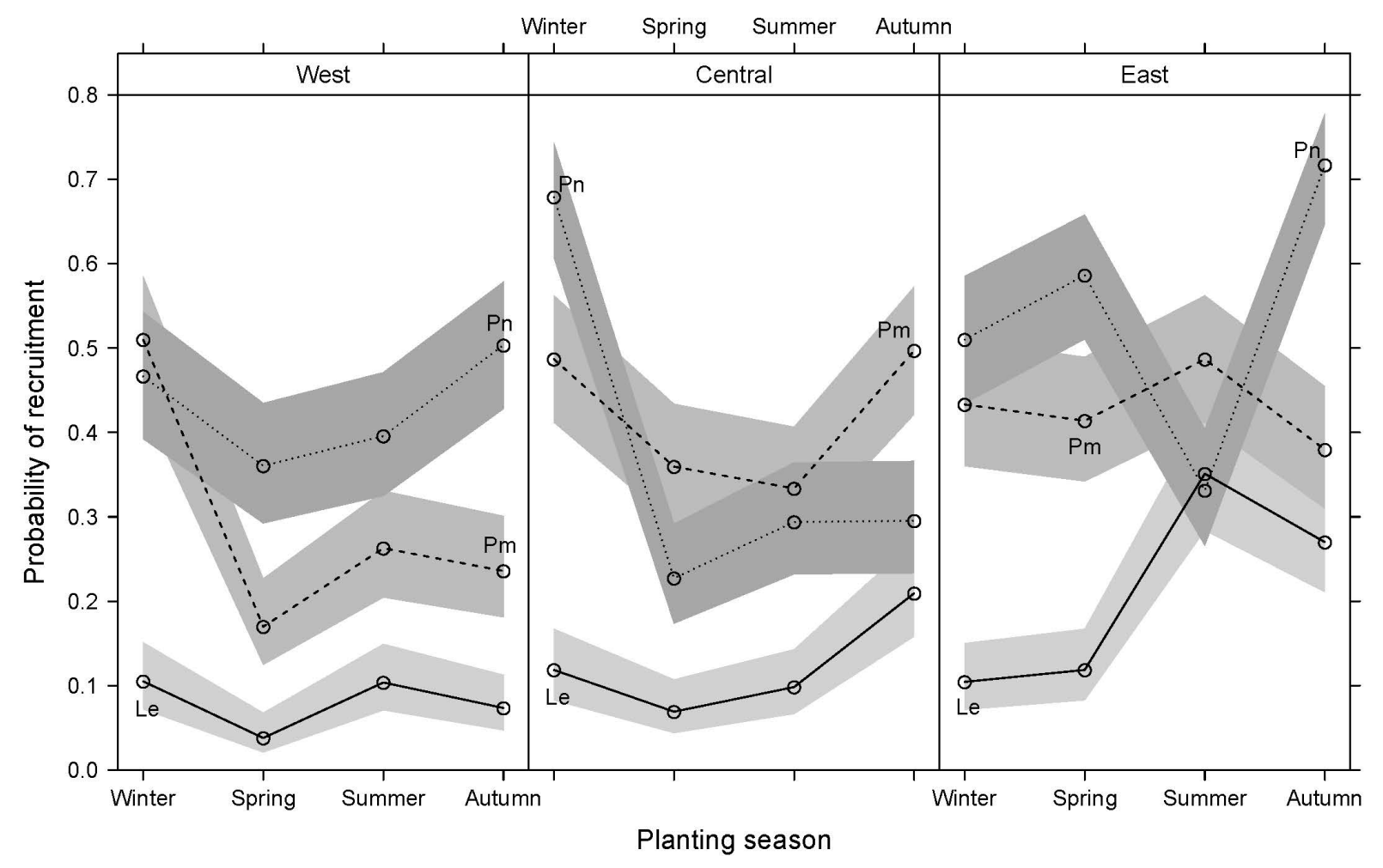

685

686 Figure 4. Predicted effects of planting season, species (Le, Leucadendron eucalyptifolium; Pm, 687 Protea mundii; Pn, P. neriifolia), and site (West, Central, East) on the probability of recruitment 688 (survival at one year post-planting) based on a generalized linear mixed model (see Table S2 for 689 model outputs). Bands show asymptotic $95 \%$ confidence intervals. 